Supplement of Biogeosciences Discuss., 12, 11587-11623, 2015

http://www.biogeosciences-discuss.net/12/11587/2015/

doi:10.5194/bgd-12-11587-2015-supplement

(C) Author(s) 2015. CC Attribution 3.0 License.

(c) (i)

Supplement of

\title{
Technical Note: An improved guideline for rapid and precise sample prepa- ration of tree-ring stable isotope analysis
}

\author{
K. Schollaen et al. \\ Correspondence to:
}

The copyright of individual parts of the supplement might differ from the CC-BY 3.0 licence. 


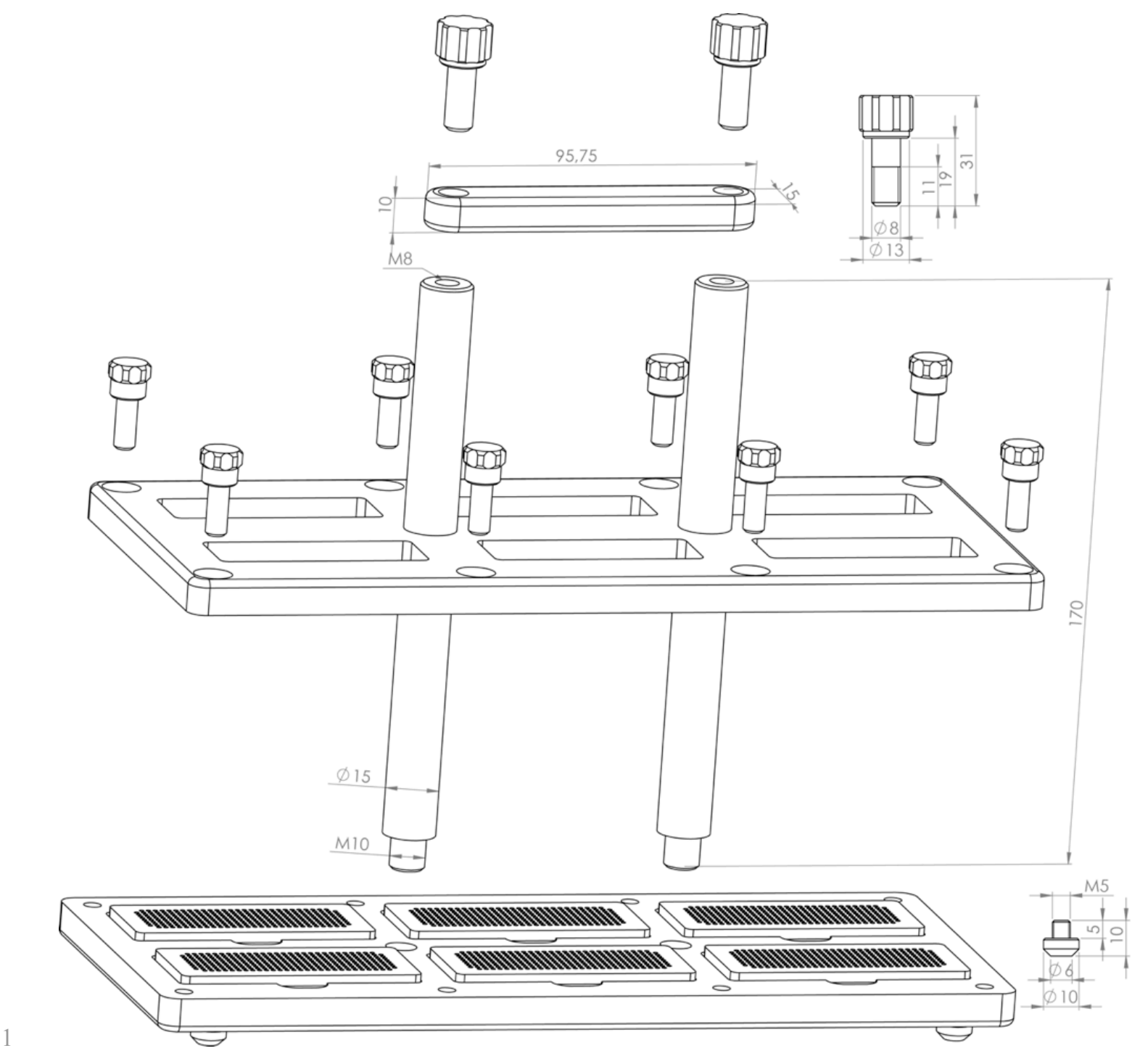

2 Figure S1a Technical design and dimensions of the extraction device. 


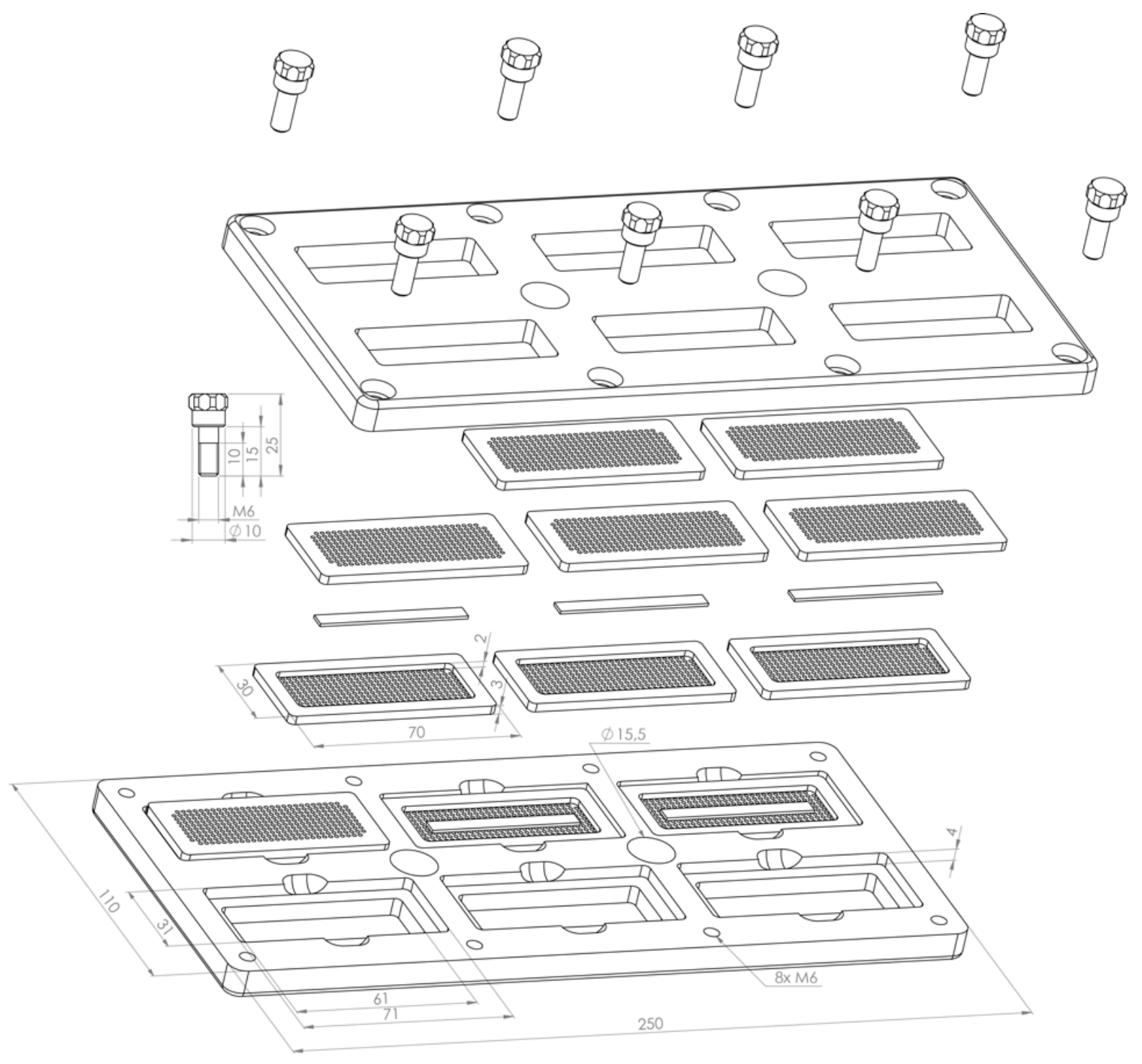

2 Figure S1b Technical design and dimensions of an individual extraction unit 
1 Notes S1 Technical notes of the extraction device.

The extraction device $(250 \times 110 \times 125 \mathrm{~mm})$ is made of two main components:

1. punching sheets function as sample holders (size: $70 \times 30 \mathrm{~mm}$ ) and

2. a casing, consisting of a lower $(250 \mathrm{~mm} \times 110 \mathrm{~mm}, 2 \mathrm{~mm}$ thick) and upper mount $(250 \mathrm{~mm} \times 110 \mathrm{~mm}, 10 \mathrm{~mm}$ thick) enclosing six rectangular wells $(71 \times 31 \mathrm{~mm}, 4$ $\mathrm{mm}$ deep) which hold the punching sheet sample holders

The chemical solutions can percolate through the punching sheet holder by rectangular holes (60 x $20 \mathrm{~mm}$ ).

Each extraction unit has two round holes (ø $25 \mathrm{~mm}$; middle hole position: 55 and $62,5 \mathrm{~mm} \mathrm{~B} / \mathrm{L}$ from left and right casing site, respectively) to give a place for bolts. The first extraction unit (bottom) has two screws threads instead of holes. The bolts have to be screwed in the first casing (bottom casing) the following units can be easily piled up of each other. On the top of the bolts a handle has been installed enabled a safety and costumer friendly handling of the device. Protruding screw heads generate sufficient space between the extraction units ensuring appropriate circulation of chemical solutions at constant temperature.

The extraction device is placed into a glass container $(250 \times 110 \times 125 \mathrm{~mm})$ that is made of single borosilicate glass plates and is glued together with aquarium glue (e.g. clear silicone waterproof sealant (Loctite), Henkel AG \& Co. KGaA, Garching, Germany). The glue is resistant against the chemicals used for cellulose extraction.

About 2.5 litres of chemical solution are necessary for each extraction step.

After each extraction process the shaking water bath, tubes and all other equipment are cleaned and dried, and metal components are treated with teflon spray to protect against corrosion due to the sodium chlorite treatment during the cellulose extraction process. 
Table S1 Site characteristics and tree species sampled.

\begin{tabular}{|c|c|c|c|c|c|}
\hline & Genus & Species & Sampling site & Altitude & Reference \\
\hline \multirow{5}{*}{$\begin{array}{l}\text { coniferous } \\
\text { wood }\end{array}$} & Pine & Pinus sylvestris & $\begin{array}{l}\text { vicinity of Zurich, } \\
\text { Switzerland }\end{array}$ & $\begin{array}{l}\text { Subfossil } \\
\text { wood }\end{array}$ & Pieper et al. (2014) \\
\hline & Larch & Larix decidua & $\begin{array}{l}\text { Lötschental, } \\
\text { Switzerland }\end{array}$ & $2000 \mathrm{~m}$ asl & Treydte et al. (2014) \\
\hline & Spruce & Picea abies & $\begin{array}{l}\text { Lötschental, } \\
\text { Switzerland }\end{array}$ & $2000 \mathrm{~m}$ asl & Treydte et al. (2014) \\
\hline & Juniper & Juniperus seravschanica & $\begin{array}{l}\text { Sary Chelek, } \\
\text { Kyrgyzstan }\end{array}$ & $1300 \mathrm{~m}$ asl & - \\
\hline & Douglas & Pseudotsuga menziesii & $\begin{array}{l}\text { vicinity of Freiburg, } \\
\text { Germany }\end{array}$ & $500 \mathrm{~m}$ asl & Jansen et al. (2013) \\
\hline \multirow{5}{*}{$\begin{array}{l}\text { angiosperm } \\
\text { wood }\end{array}$} & Oak & Quercus robur & $\begin{array}{l}\text { Telegrafenberg, } \\
\text { Germany }\end{array}$ & $60 \mathrm{~m}$ asl & - \\
\hline & Teak & Tectona grandis & Donoloyo, Indonesia & $380 \mathrm{~m}$ asl & Schollaen et al. (2013) \\
\hline & Cedar & Cedrela lilloi & Purissima, Bolivia & - & Brienen et al. (2012) \\
\hline & Baobab & Adansonia digitata & $\begin{array}{l}\text { Klein Bolayi, South } \\
\text { Africa }\end{array}$ & $571 \mathrm{~m}$ asl & Slotta et al. (2014) \\
\hline & Beech & Fagus sylvatica & $\begin{array}{l}\text { Telegrafenberg, } \\
\text { Germany }\end{array}$ & $60 \mathrm{~m}$ asl & - \\
\hline
\end{tabular}

\section{References}

Brienen, R.J.W., Helle, G., Pons, T.L., Guyot, J.L., Gloor, M., 2012. Oxygen isotopes in tree rings are a good proxy for Amazon precipitation and El Niño-Southern Oscillation variability. Proceedings of the National Academy of Sciences 109, 16957-16962.

Jansen, K., Sohrt, J., Kohnle, U., Ensminger, I., Gessler, A., 2013. Tree ring isotopic composition, radial increment and height growth reveal provenance-specific reactions of Douglas-fir towards environmental parameters. Trees 27, 37-52.

Pieper, H., Brauer, A., Miramont, C., Nievergelt, D., Büntgen, U., Helle, G., 2014. Annually resolved stable chronologies from Lateglacial Central European tree rings, EGU General Assembly 2014, Vienna, Austria.

Schollaen, K., Heinrich, I., Neuwirth, B., Krusic, P.J., D'Arrigo, R.D., Karyanto, O., Helle, G., 2013. Multiple tree-ring chronologies (ring width, $\delta^{13} \mathrm{C}$ and $\delta^{18} \mathrm{O}$ ) reveal dry and rainy season signals of rainfall in Indonesia. Quaternary Science Reviews 73, 170-181.

Slotta, F., Riedel, F., Heußner, K.-U., Helle, G., 2014. The African Baobab - a high-resolution archive for climate variability of semi-arid Africa?, $9^{\text {th }}$ International Conference on Dendrochronology, Melbourne, Australia.

Treydte, K., Boda, S., Graf Pannatier, E., Fonti, P., Frank, D., Ullrich, B., Saurer, M., Siegwolf, R., Battipaglia, G., Werner, W., Gessler, A., 2014. Seasonal transfer of oxygen isotopes from precipitation and soil to the tree ring: source water versus needle water enrichment. New Phytol 202, 772-783. 